\title{
Evaluasi Penerapan Tata Kelola Bank Pada PT BPR Eka Bumi Artha
}

\author{
Wangsit Supeno $^{1}$, Vina Islami ${ }^{2}$ \\ ${ }^{1}$ Universitas Bina Sarana Informatika, \\ wangsit.wss@bsi.ac.id \\ ${ }^{2}$ Universitas Bina Sarana Informatika, \\ vina.vii@bsi.ac.id
}

\author{
(Supeno \& Islami, 2019) \\ Supeno, W., \& Islami, V. (2019). Evaluasi Penerapan Tata Kelola Bank Pada PT BPR Eka Bumi Artha. Moneter, \\ $6(2), 157-166$.
}

\begin{abstract}
The application of good governance of the Rural Bank or BPR banks is an obligation that must be implemented on an ongoing basis. A number of BPR closed operations due to experiencing problems in governance. The increase in the business volume of BPR is increasing the risks involved, thereby encouraging the need for the implementation of governance by BPR. With respect to the issue of the BPR and in order to create a healthy and robust BPR industry, and improve the performance of BPR, protect stakeholders, and improve compliance with legislation, as well as of ethical values that are generally applicable to banking. BPR as a bank financial institution need to implement governance immediately. Financial Services Authority as a regulator in the year 2015 has issued regulation of the Financial Services Authority No. 4/POJK. 03/2015 concerning the implementation of governance for the Rural Bank. The research object for implementing governance in accordance with the Financial Services Authority regulation is BPR Eka Bumi Artha. The research method was done qualitatively with the source of the report on BPR governance of Eka Bumi Artha in 2018 that has been published. The results showed BPR Eka Bumi Artha has implemented the good word, by applying the principles of transparency, accountability, responsibility, Independence, and fairness. From the results of the evaluation as a whole based on the data governance in 2018, BPR Eka Bumi Artha has carried out the governance pursuant to Article 2 regulation of the Financial Services Authority No. 4/POJK. 03/2015 concerning the implementation of governance for the Rural Bank.
\end{abstract}

Keywords: Evaluation, Application, Good Corporate Governance

\section{PENDAHULUAN}

Permasalahan Tata kelola yang baik telah terjadi pada Bank Perkreditan Rakyat (BPR) di Indonesia, karena tata kelola yang buruk telah menjadi alasan sejumlah Bank Perkreditan Rakyat (BPR) di Indonesia ditutup. Hal ini sesuai dengan pernyataan dari Deputi Senior Bank Indonesia Mirza Adityaswara yang mengemukakan alasan penutupan BPR dikarenakan BPR berkinerja buruk yang disebabkan oleh kelalaian dalam mengelola BPR dan kasus penipuan (Fraud). (Nurdin, 2015).

Berkaitan dengan hal tersebut maka penelitian tata kelola perusahaan yang baik ini penting untuk dilakukan, khususnya di Bank Perkreditan Rakyat (BPR) yang pada saat ini menghadapi persaingan yang ketat dan risiko usaha yang semakin besar. Penelitian ini berhubungan dengan implementasi Peraturan Otoritas Jasa Keuangan (POJK) Nomor 4/POJK.03/2015 tentang Penerapan Tata Kelola Bagi Bank Perkreditan Rakyat (Otoritas Jasa Keuangan, 2015). Peraturan tersebut diterbitkan dengan mempertimbangkan pada semakin meluasnya pelayanan disertai peningkatan volume usaha Bank Perkreditan Rakyat, maka semakin meningkat pula risiko Bank Perkreditan Rakyat sehingga mendorong kebutuhan terhadap penerapan tata kelola oleh Bank Perkreditan Rakyat (BPR) memperhatikan pada permasalahan BPR serta dalam rangka untuk menciptakan industri BPR yang sehat dan kuat. Selain itu juga, tata kelola dalam rangka meningkatkan kinerja Bank Perkreditan Rakyat, melindungi pemangku kepentingan (stakeholders), dan meningkatkan kepatuhan terhadap peraturan perundang-undangan, serta nilai-nilai etika yang berlaku umum pada Perbankan, Bank Perkreditan Rakyat perlu segera menerapkan tata kelola.

Hasil penelitian (Sundari, 2014) atas evaluasi penerapan GCG pada Bank PD BPR Sarimadu, menunjukkan bahwa terdapat pengaruh penerapan prinsip-prinsip good corporate governance terhadap kinerja perusahaan. Sejak pertama kali menerapkan prinsip-prinsip Good Corporate Governance sampai 
saat ini berhasil menekan tingkat resiko kredit dengan trend semakin menurun.

Hasil uji hipotesis dalam penelitian (Sawitri \& Ramantha, 2018), diperoleh hasil bahwa Tata Kelola atau Good Corporate Governance (GCG) berpengaruh positif pada kinerja Bank Perkreditan Rakyat di Kota Denpasar. Hal ini terjadi karena GCG membantu pengelola BPR untuk mengatur bagaimana perusahaan dioperasikan dan dijalankan dengan baik. GCG ini juga adalah sebagai sarana interaksi yang mengatur antar struktur dan mekanisme yang menjamin adanya kontrol, namun tetap mendorong efisiensi dan kinerja pada BPR.

Studi Miswan Gumanti dan Desi Handayani dalam (Dharmawan \& Kurniawan, 2018) mengindikasikan bahwa peningkatan kualitas GCG diperlukan dalam rangka peningkatan kualitas manajemen bank agar praktik perbankan yang tidak sehat dapat diminimalisir. Apabila bank tidak memiliki manajemen yang baik, dapat menimbulkan risiko operasional baik pada sistem, prosedur maupun sumber daya manusia.

Berdasarkan pada uraian di atas dan didukung dengan penelitian yang pernah dilakukan serta Peraturan Otoritas Jasa Keuangan (POJK) Nomor 4/POJK.03/2015 tentang Penerapan Tata Kelola bagi Bank Perkreditan Rakyat, maka penulis tertarik untuk melakukan penelitian dengan mengkaji sejauh mana penerapan Tata Kelola yang Baik (GCG) dalam operasional PT BPR Eka Bumi Artha berdasarkan pada laporan Tata Kelola BPR Eka yang telah dipublikasikan pada tahun 2018.

PT BPR Eka Bumi Artha adalah sebuah lembaga keuangan bank terbesar di Indonesia dan sejak tahun 2011 selalu menerima penghargaan sebagai BPR terbaik. BPR Eka Bumi Artha memiliki kantor pusat di Jl. Ahmad Yani Metro Lampung. Sejak tahun 2017 sampai dengan 2018, sesuai peraturan Otoritasa jasa Keuangan, PT BPR Eka Bumi Artha selalu mempublikasikan laporan penerapan tata kelola perusahaan di website PT BPR Eka Bumi Artha yang dapat diakses oleh masyarakat.

Permasalahan dalam penelitian ini berkaitan dengan bagaimana BPR Eka menerapkan prinsip-prinsip tata kelola BPR yang sehat sesuai Peraturan Otoritas Jasa Keuangan Nomor 4/POJK.03/2015 tentang Penerapan Tata Kelola Bagi Bank Perkreditan Rakyat, dan perlunya BPR Eka menindak lanjuti aspek-aspek negatif jika ditemukan dalam penilaian sendiri (self assessment) atas penerapan tata kelola yang selama ini dilakukan sebab bisa berdampak pada kinerja BPR di masa yang akan datang.

Ruang lingkup penelitian adalah membahas penerapan prinsip-prinsip tata kelola perusahaan sesuai Peraturan Otoritas Jasa Keuangan Nomor 4/POJK.03/2015 tentang Penerapan Tata Kelola Bagi Bank Perkreditan Rakyat pada BPR Eka Bumi Artha, dibatasi hanya yang telah terlaksana pada tahun 2018 . Tujuan penelitian ini adalah untuk mengevaluasi sejauhmana PT BPR Eka Bumi Artha sebagai BPR yang memiliki volume usaha sangat besar dan setiap tahun menerima penghargaan atas kinerjanya, telah menerapkan Prinsip-Prinsip Tata Kelola Perusahaan yang Baik (Good Corporate Governance) sesuai Peraturan Otoritas Jasa Keuangan (POJK) Nomor 4/POJK.03/2015 tentang Penerapan Tata Kelola Perusahaan (Good Corporate Govarnance) bagi Bank Perkreditan Rakyat berdasarkan pada Laporan Tata Kelola PT BPR Eka Bumi Artha tahun 2018.

\section{Bank Perkreditan Rakyat (BPR)}

Bank Perkreditan Rakyat (BPR) adalah sebuah lembaga keuangan bank yang operasionalnya diatur dalam Undang-undang Perbankan Nomor 10 Tahun 1998 sebagai perubahan dari Undang-undang Nomor 7 Tahun 1992 tentang Perbankan, adalah bank yang melaksanakan kegiatan usaha secara konvensional dan/atau berdasarkan prinsip syariah yang dalam kegiatannya tidak memberikan jasa dalam lalu lintas pembayaran (Supeno, 2019).

Menurut Triandanu dalam (Supeno, 2017) kegiatan usaha yang utama dari suatu bank adalah penghimpunan dana dan penyaluran dana. Penyaluran dana dengan tujuan untuk memperoleh penerimaan akan dapat dilakukan apabila dana telah dihimpun.

Dalam penerapan Tata Kelola yang Baik, BPR memiliki kewajiban memberikan pelayanan yang berkualitas dan transparan kepada nasabah sehingga dapat meningkatkan kinerja BPR. Menurut Tjiptono dalam (Riyanto, 2018) definisi kualitas pelayanan berfokus pada upaya memenuhan kebutuhan dan keinginan konsumen serta ketepatan penyampaian untuk mengimbangi harapan konsumen.

Menurut Suryani \& Sartika dalam (Kurniasari, 2019) Pelayanan pelanggan merupakan penunjang dalam memasarkan produk barang atau jasa yang menitik beratkan kepada upaya pendekatan, keyakinan dan kepuasan konsumen. Dengan pelayanan perusahaan dapat menciptakan kekhususan dalam menjalankan kegiatan usaha dari para pesaing

\section{Tata Kelola Perusahaan yang Baik}

Menurut Peraturan Bank Indonesia Nomor 8/4/PBI/2006 tentang Pelaksanaan Good Corporate Governance Bagi Bank Umum, Good Corporate Governance adalah suatu tata kelola bank yang menerapkan prinsip-prinsip keterbukaan (transparency), akuntabilitas (accountability), pertanggung jawaban (responsibility), independensi (Independency), dan juga kewajaran (fairness). (Wijayanti \& Hutapea, 2019).

Menurut Tjager dalam (Sawitri \& Ramantha, 2018), Penerapan good corporate governance merupakan suatu kumpulan pemikiran yang bertumpu pada hak pemegang saham untuk memperoleh informasi dengan benar, akurat, dan tepat waktu, sehingga tidak memandang perusahaan public maupun non public tetap harus menganggap bahwa Good Corporate Governance (GCG) bukan hanya sebagai hiasan 
tetapi juga sebagai upaya peningkatan kinerja dan nilai perusahaan.

Menurut (Fajri, 2017), dalam Undang-Undang Nomor 40 Tahun 2007 tentang Perseroan Terbatas, dinyatakan bahwa prinsip-prinsip Good Corporate Govarnance (GCG) harus mencerminkan hal-hal sebagai berikut:

a. Keterbukaan (Transparancy), yaitu keterbukaan dalam melaksanakan proses pengambilan keputusan dan keterbukaan dalam mengemukakan informasi materiil dan relevan mengenai perusahaan.

b. Akuntabilitas (Accountability), yaitu kejelasan pembagian tugas, wewenang, dan tanggung jawab masing-masing organ perusahaan yang diangkat setelah melalui fit and proper test, sehingga pengelolaan perusahaan dapat dilaksanakan secara efektif dan efisien.

c. Pertanggungjawaban (Responsibility), yaitu perwujudan kewajiban organ perusahaan untuk melaporkan kesesuaian pengelolaan perusahaan dengan pengaturan perundang-undangan yang berlaku, dan berhasil maupun kegagalannya dalam pencapaian visi, misi, tujuan, dan sasaran perusahaan yang telah ditetapkan.

d. Independensi (Independency), yaitu suatu keadaan perusahaan dikelola secara profesional tanpa benturan kepentingan dan pengaruh atau tekanan dari pihak manapun, terutama pemegang saham mayoritas, yang bertentangan dengan peraturan perundang-undangan yang berlaku dan prinsip-prinsip korporas yang sehat.

e. Kewajaran (Fairness), yaitu keadilan dan kesetaraan didalam memenuhi hak-hak stakeholders yang timbul berdasarkan perjanjian dan peraturan perundang-undangan berlaku.

\section{Prinsip dan Regulasi Tata Kelola BPR}

Menurut Peraturan Otoritas Jasa Keuangan Nomor 4/POJK.03/2015 tentang Penerapan Tata Kelola Bagi Bank Perkreditan Rakyat (Otoritas Jasa Keuangan, 2015), Tata Kelola adalah tata kelola BPR yang menerapkan prinsip-prinsip keterbukaan (transparency), akuntabilitas (accountability), pertanggung jawaban (responsibility), independensi (independency), dan kewajaran (fairness).

Berdasarkan Pasal 2 POJK No. 4/POJK.03 / 2015 tentang Penerapan Tata Kelola Bagi Bank Perkreditan Rakyat (Otoritas Jasa Keuangan, 2015) berbunyi:

a. BPR wajib menerapkan Tata Kelola dalam setiap kegiatan usahanya pada seluruh tingkatan atau jenjang organisasi.

b. Penerapan Tata Kelola sebagaimana dimaksud pada ayat (1) paling sedikit harus diwujudkan dalam bentuk:

1). Pelaksanaan tugas dan tanggung jawab Direksi;

2). Pelaksanaan tugas dan tanggung jawab Dewan
Komisaris;

3). Kelengkapan dan pelaksanaan tugas atau fungsi komite;

4). Penanganan benturan kepentingan;

5). Penerapan fungsi kepatuhan, audit intern, dan audit ekstern;

6). Penerapan manajemen risiko, termasuk sistem pengendalian intern;

7). Batas maksimum pemberian kredit;

8). Rencana bisnis BPR;

9). Transparansi kondisi keuangan dan non keuangan.

Selanjutnya berdasarkan Pasal 76 POJK Nomor 4/POJK.03/2015 tentang Penerapan Tata Kelola Bagi Bank Perkreditan Rakyat (Otoritas Jasa Keuangan, 2015) BPR memiliki kewajiban terkait laporan tata kelola BPR sebagai berikut:

a. BPR wajib menyampaikan laporan penerapan Tata Kelola sebagaimana dimaksud dalam Pasal 75 paling lambat 4 (empat) bulan setelah tanggal 31 Desember kepada pemegang saham dan paling sedikit kepada:

1). Otoritas Jasa Keuangan;

2). Asosiasi BPR di Indonesia; dan

3). 1 (satu) kantor media atau majalah ekonomi dan keuangan.

b. Bagi BPR yang telah memiliki situs web wajib menginformasikan laporan penerapan Tata Kelola sebagaimana dimaksud pada ayat (1) pada laman (homepage) BPR paling lambat 4 (empat) bulan setelah tanggal 31 Desember.

Menurut Nganga, Jain and Artivor dalam (Mudashiru, Bakare, Babatunde, \& Ishmael, 2014) menyebutkan, "strengthen corporate governance beyond the distribution of rights and responsibilities of different stakeholders with vested interest in corporate organisations to consider the importance of protection of stakeholders, particularly in relation to how well corporate organisations are managed". Menurut (Fajri, 2017) diterapkannya prinsip-prinsip GCG dalam sistem menajemen Bank BPR sangat penting dalam meningkatkan keberhasilan suatu perusahaan yang bergerak di bidang perbankan. Sudah menjadi keharusan bagi manajemen bank untuk menyuarakan transparency, accountability, responsibility, independency dan fairness sebagaimana prinsip-prinsip GCG yang ada dalam proses manajemen perusahaan yang di akomodasi dari peraturan Undang-Undang No. 40 Tahun 2007.

\section{METODOLOGI PENELITIAN}

Obyek penelitian ini adalah Bank Perkreditan Rakyat (BPR) Eka Bumi Artha yang memiliki kantor pusat operasional di Metro Lampung.

Metode penelitian yang digunakan adalah deskriptif kualitatif, dengan menggunakan data sekunder bersumber dari website BPR Eka Bumi Artha di mana sesuai ketentuan Otoritas Jasa Keuangan, BPR Eka berkewajiban untuk mempublikasikan Laporan 
Tata Kelola BPR setiap tahun, laporan Keuangan Publikasi setiap tri wulan, serta informasi terkait lainnya yang bisa diakses. Data yang digunakan dalam penelitian ini adalah data pelaksanaan tata kelola BPR Eka pada tahun 2018.

Menurut Moleong dalam (Supeno, 2018), penelitian kualitatif adalah penelitian yang bermaksud untuk memahami fenomena tentang apa yang dialami oleh subyek penelitian misalnya perilaku, persepsi, motivasi, tindakan, dan lain-lain, secara holistik, dan dengan cara deskripsi dalam bentuk kata-kata dan bahasa, pada suatu konteks khusus yang alamiah dan dengan memanfaatkan berbagai metode alamiah.

\section{HASIL DAN PEMBAHASAN}

\section{Penerapan Prinsip-Prinsip Tata Kelola Bank}

Berdasarkan hasil penelitian, penerapan prinsip- Tata Kelola BPR Eka sudah sesuai dengan Peraturan Otoritas Jasa Keuangan Nomor 4/POJK.03/2015 tentang Penerapan Tata Kelola Bagi Bank Perkreditan Rakyat. Dalam penelitian ini Penulis meneliti sejauh mana PT BPR Eka menerapkan prinsip-prinsip Tata Kelola Perusahaan yang Baik dengan berdasarkan pada laporan Tata Kelola tahun 2018 yang dipublikasikan pada website BPR Eka. Prinsip-pinsip Tata Kelola yang telah diterapkan BPR Eka pada tahun 2018 sebagai berikut:

a. Keterbukaan (Transparancy)

Penelitian dilakukan berdasarkan laporan Tata Kelola BPR tahun 2018 terkait transparansi, menunjukkan bahwa BPR Eka telah memiliki Direksi dan Dewan Komisaris beserta tugas dan tanggung jawabnya secara lengkap. Dalam rapatrapat Direksi secara keseluruhan hadir yang menunjukkan adanya kepatuhan.

BPR Eka membuat laporan keuangan sesuai peraturan yang berlaku secara tepat waktu dan telah mempublikasikannya, baik untuk laporan keuangan triwulanan maupun laporan keuangan tahunan. Laporan keuangan tahunan disusun sesuai dengan standar akuntansi yang berlaku untuk BPR, dan diaudit oleh kantor akuntan publik yang telah terdaftar di Otoritas Jasa Keuangan. Untuk laporan keuangan publikasi disajikan dan ditanda tangani oleh Direksi. Dalam hal laporan non keuangan bank, BPR Eka telah memberikan informasi mengenai produk secara jelas, informasi ini dapat diperoleh secara mudah oleh nasabah seperti, penjelasan langsung dari petugas terkait, banner, brosur atau bentuk tertulis lainnya di seluruh kantor.

BPR Eka transparan dalam menyediakan dan menginformasikan tata cara pengaduan nasabah dan sengketa kepada nasabah sesuai ketentuan Otoritas Jasa Keuangan mengenai pengaduan nasabah. Dalam laporan tata kelola BPR Eka selama tahun 2018, terdapat pengaduan 100 nasabah yang telah diselesaikan keseluruhannya. Penerapan transparansi dalam kaitannya dengan pemegang saham, Direksi selalu mengungkapkan seluruh Kepemilikan Saham BPR Eka. Diungkapkan juga kepemilikan saham para Direksi baik di BPR Eka atau di perusahaan lain. Laporan tata kelola ini juga mengungkapkan hubungan keuangan dan atau hubungan keluarga dengan anggota Dewan Komisaris, anggota Direksi lain dan/ atau pemegang saham BPR Eka. BPR Eka melakukan rapat Direksi dengan Komisaris, menyampaikan RUPS/RUPSLB untuk menjadi bahan keputusan bersama dan telah mendapatkan persetujuan dari Direksi dan Dewan Komisaris BPR Eka. Dalam laporan tata kelola bank, BPR Eka juga mengungkapkan transparansi mengenai Remunerasi dan fasilitas lainnya untuk Direksi dan Dewan Komisaris, serta rasio gaji tertinggi dan terendah Direksi, Komisaris dan Pegawai.

BPR Eka telah menyusun Rencana Bisnis baik jangka pendek, jangka menengah maupun jangka panjang secara transparan, dan selalu dilaporkan kepada Otoritas Jasa Keuangan sesuai ketentuan yang berlaku.

Berdasarkan penjelasan di atas, BPR Eka dalam usahanya dinilai telah menerapkan prinsip Keterbukaan (Transparancy) sebagai bagian dalam tata kelola perusahaan yang baik. Hal ini tentunya akan berdampak pada meningkatkan kepercayaan nasabah dan masyarakat kepada BPR Eka. Masyarakat memiliki kemudahan untuk mengetahui tata kelola BPR Eka, termasuk dapat mengakses kinerja BPR melalui website BPR Eka, yang selama ini sudah dikenal baik dan setiap tahun mendapat penghargaan Infobank Award sejak tahun 2011.

b. Akuntabilitas (Accountability)

Yaitu kejelasan fungsi dan pelaksanaan pertanggung jawaban organ BPR sehingga pengelolaan usaha berjalan secara efektif.

Berdasarkan penilaian pada laporan tatakelola Akuntabilitas BPR Eka, dijelaskan mengenai tugas, tanggung jawab dan wewenang Direksi dan Dewan Komisaris, selaras dengan visi dan misi perusahaan. Jumlah Anggota Direksi BPR Eka berjumlah 3 (tiga) orang dan telah memenuhi Peraturan Otoritas Jasa Keuangan Nomor 4/POJK.03/2015 tentang Penerapan Tata Kelola Bagi Bank Perkreditan Rakyat tanggal 31 Maret 2015 yang menetapkan paling sedikit 3 (tiga) orang anggota Direksi. Dalam hal Dewan Komisaris jumlahnya tidak melampaui jumlah anggota Direksi. Penugasan anggota Direksi dan Dewan Komisaris BPR Eka telah didasarkan pada: Sertifikasi kelulusan profesi BPR (Certif); Uji kemampuan dan kepatutan (fit and proper test) sesuai ketentuan Otoritas Jasa Keuangan; dan adanya pencatatan dalam administrasi Otoritas Jasa Keuangan No. S-163/ KO.0741/ 2017 tanggal 13 Juli 2017.

Berdasarkan pada penjelasan tersebut di atas, 
menunjukkan bahwa BPR Eka telah memiliki kejelasan fungsi, tanggung jawab dan kewenangan Direksi dan Dewan Komisaris. Dengan didukung pada proses penugasan yang jelas dimulai dari kewajiban mengikuti sertifikasi, fit and proper dan pencatatan administrasi sesuai peraturan Otoritas Jasa Keuangan yang menunjukkan bahwa prinsip Tata Kelola Perusahaan yang Baik berupa Akuntabilitas telah dilaksanakan sebagai-mana mestinya sesuai regulasi.

c. Pertanggungjawaban (Responsibility)

Yaitu kesesuaian pengelolaan BPR dengan peraturan perundang-undangan yang berlaku dan prinsip-prinsip pengelolaan yang sehat. Berkaitan dengan prinsip ini, seluruh Direksi dan Dewan Komisaris telah dinyatakan Kompeten dalam sertifikasi profesi Direksi BPR yang dikeluarkan oleh Lembaga Profesi Certif, sesuai ketentuan dari Badan Nasional Sertifikasi Profesi (BNSP). Selain itu, Direksi dan Komisaris BPR Eka dalam penugasannya telah melalui sebuah proses Uji Kelayakan dan Kepatutan (fit \& proper). Penugasan Direksi dan Dewan Komisaris juga sudah dicatat dalam administrasi Otoritas Jasa Keuangan No.S-163/KO.0741/2017 tanggal 13 Juli 2017.

Seluruh anggota Direksi BPR Eka telah melakukan pengembangan dan peningkatan kemampuan melalui berbagai kegiatan seminar, pelatihan, workshop, dan/atau kegiatan serupa lainnya tentang perbankan untuk mendukung pelaksanaan tugas dan tanggung jawabnya. Direksi dan Dewan Komisaris dalam pelaksanaan tugasnya didukung komite-komite yaitu; Komite Audit, Komite Pemantau Risiko, dan Satuan Kerja Audit Intern,

Berdasarkan pada penjelasan tersebut di atas, BPR Eka dikelola oleh orang-orang yang kompeten dengan melalui proses uji Kelayakan dan Kepatutan (Fit and Proper) dari Otoritas Jasa Keuangan, didukung pengembangan dan peningkatan kemampuan yang secara kontinyu dilakukan. Hal ini menunjukkan bahwa prinsip Tata Kelola Perusahaan yang Baik berupa Pertanggung Jawaban (responsibility) telah sesuai dengan ketentuan yang berlaku.

d. Independensi (Independency)

Independensi tata kelola bank yang baik, dijelaskan dalam laporan tata kelola BPR Eka, yaitu mayoritas anggota Direksi, tidak memiliki hubungan kepemilikan, hubungan keluarga atau semenda sampai dengan derajat kedua dengan sesama anggota direksi; dan/atau Anggota Dewan Komisaris.

Independensi juga ditunjukkan dengan anggota direksi baik secara sendiri-sendiri maupun bersama-sama tidak memiliki saham sebesar $25 \%$ atau lebih dari modal disetor pada BPR Eka dan/atau menjadi pemegang saham mayoritas di lembaga jasa keuangan non bank.

Dalam hal independensi Dewan Komisaris, mayoritas anggota Dewan Komisaris, tidak memiliki hubungan keluarga atau semenda sampai dengan derajat kedua dengan sesama anggota Dewan Komisaris, dan/atau anggota Direksi. Selanjutnya Independensi juga untuk Anggota Komite Audit, yang dalam hal ini tidak memiliki hubungan keuangan, kepemilikan dan keluarga atau semenda sampai dengan derajat kedua dengan sesama anggota Dewan Komisaris, anggota Direksi, dan/atau pemegang saham pengendali.

Berdasarkan penjelasan independensi di atas, menunjukkan bahwa pengelolaan BPR Eka dilakukan secara profesional, bebas dan obyektif tanpa pengaruh atau segala tekanan dari pihak manapun. Dengan menerapkan pada prinsip independensi dalam pengelolaan usaha, benturan kepentingan (conflict of interest) dan dominasi yang tidak wajar oleh stakeholders dapat dihindari dan tidak terjadi pada tahun 2018.

e. Kewajaran (Fairness)

Yaitu keadilan dan kesetaraan dalam memenuhi hak hak pemangku kepentingan (stake holders) yang timbul berdasarkan perjanjian dan peraturan perundang-undangan yang berlaku. Dalam penerapan tata kelola yang baik yaitu Kewajaran, menjadi komitmen bersama dari seluruh jajaran manajemen dan karyawan untuk mematuhi dan menjalankan operasional, dengan menjunjung tinggi semua peraturan Otoritas Jasa Keuangan, Bank Indonesia, PPATK, LPS dan perundangundangan yang berlaku. Direksi dan Komisaris menerima remunerasi dan fasilitas lainnya yang ditetapkan berdasarkan keputusan Rapat Umum Pemegang Saham (RUPS) dengan memperhatikan pada kewajaran dan/ atau kesesuaian dengan peraturan perundangundangan. Dalam menerapkan prinsip kewajaran terkait gaji, diungkapkan dalam bentuk rasio gaji tertinggi dan terendah dalam skala perbandingan. Berdasarkan hasil penelitian terhadap penerapan prinsip kewajaran, menunjukkan bahwa BPR Eka dalam tata kelola bank telah mengikuti peraturan perundang-undangan yang berlaku sehingga dapat menciptakan kesetaraan. Begitu juga dalam hal penetapan gaji pegawai, BPR Eka didasarkan pada perhitungan yang matang sehingga memperhatikan prinsip kewajaran.

\section{Evaluasi Penerapan Tata Kelola BPR}

Penerapan tata kelola bank oleh BPR Eka sesuai dengan Peraturan Otoritas Jasa keuangan Nomor 4/POJK.03/2015 tentang Penerapan Tata Kelola Bagi Bank Perkreditan Rakyat meliputi:

a. Tata Kelola Pelaksanaan Tugas dan Tanggung Jawab Direksi;

Dalam penerapan tata kelola BPR, pelaksanaan tugas dan tanggung jawab Direksi BPR Eka, 
mengacu pada anggaran dasar BPR, peraturan perundang-undangan, dan termasuk ketentuan OJK yang mengatur mengenai pelaksanaan tugas dan tanggung jawab Direksi. Dalam laporan tata kelola BPR Eka tahun 2018, menunjukkan bahwa jumlah Direksi BPR Eka telah memenuhi ketentuan Peraturan Otoritas Jasa Keuangan Nomor 4/POJK.03/2015.Sesuai jumlah Aset BPR Eka, anggota Direksi minimal tiga orang.

Dalam penugasan jabatan anggota direksi PT BPR Eka Bumi Artha, telah memenuhi Peraturan yang berlaku. Persyaratan yang telah dipenuhi adalah memiliki Sertifikat Kompetensi dari LSP Certif sesuai BNSP, telah lulus dalam proses uji kelayakan dan kepatutan (fit and proper), dan telah didaftarkan dalam pencatatan administrasi Otoritas Jasa Keuangan No.5-163/KO.0741/2017 tanggal 13Juli 2017. Selain itu juga dilaporkan pula mengenai hubungan keuangan dan/atau hubungan keluarga dengan anggota Dewan Komisaris, anggota Direksi lain dan/atau pemegang saham BPR Eka.

Dalam meningkatkan profesi sebagai Direksi BPR, anggota Direksi melakukan pengembangan dan peningkatan kemampuan melalui berbagai kegiatan seminar, pelatihan, workshop dan/atau kegiatan serupa lainnya tentang perbankan untuk mendukung tugas dan tanggung jawabnya.

Direksi memiliki tugas dan tanggung jawab yang terinci sehingga dapat dipahami oleh seluruh anggota. Dalam pelaksanaan kepengurusan BPR Eka, di antaranya Direksi wajib mengelola BPR Eka sesuai kewenangan dan tanggung jawab sebagaimana diatur dalam Anggaran dasar BPR Eka, Pedoman dan tata tertib kerja Direksi serta peraturan perundang-undangan yang berlaku.

Dalam rangka melaksanakan tata kelola pada setiap kegiatan usaha BPR Eka di seluruh tingkatan atau jenjang organisasi, Direksi telah membentuk paling sedikit: Satuan Kerja Audit Intern (SKAI), Satuan Kerja Manajemen Risiko dan Komite Manajemen Risiko serta Satuan Kerja Kepatuhan.

Direksi BPR Eka mematuhi peraturan yang berlaku mengenai larangan yang telah disepakati di antaranya anggota Direksi dilarang menggunakan bank Eka untuk kepentingan pribadi atau keluarga, dan/atau pihak lain yang dapat merugikan atau mengurangi keuntungan BPR Eka. Dalam laporan tata kelola BPR 2018, menunjukkan adanya transparansi Direksi dalam hal kepemilikan saham Direksi di BPR Eka dan diperusahaan lain.

Berdasarkan penjelasan di atas menunjukkan bahwa BPR Eka telah menerapkan tata kelola yang baik dalam hal pelaksanaan tugas dan tanggung jawab Direksi secara transparan sesuai dengan peraturan dan perundang-undangan yang berlaku. Dengan kompetensi yang dimiliki Direksi dan mematuhi peraturan yang berlaku, maka tata kelola yang baik dapat diterapkan.

b. Tata Kelola Pelaksanaan Tugas dan Tanggung Jawab Dewan Komisaris

Dalam laporan tata kelola BPR Eka tahun 2018, menunjukkan bahwa jumlah Dewan Komisaris BPR Eka telah memenuhi ketentuan Peraturan Otoritas Jasa Keuangan Nomor 4/POJK.03/2015 tentang Penerapan Tata Kelola Bagi Bank Perkreditan Rakyat tanggal 31 Maret 2015. Berdasarkan pada Rapat Umum Pemegang Saham (RUPS) PT BPR Eka Bumi Artha yang dituangkan dalam Akte No. 1 tanggal 14Juni 2017, anggota Dewan Komisaris. Anggota Dewan Komisaris BPR Eka terdiri atas, jabatan Komisaris Utama bapak Awet Abadi, jabatan Komisaris bapak Muji dan bapak Johansyah Abu Bakar. Diketahui terdapat hubungan keluarga antara Komisaris utama dengan Direktur Kepatuhan.

Dewan Komisaris BPR Eka mempunyai tugas dan tanggung jawab untuk mematuhi perundangundangan yang berlaku di Indonesia, termasuk namun tidak terbatas pada peraturan terkait pelaksanaan Good Corporate Governance, Undang-undang Perseroan Terbatas, Undangundang Perbankan, Peraturan Otoritas jasa Keuangan dan Peraturan Bank Indonesia serta memastikan dilaksanakannya ketentuanketentuan Anggaran Dasar BPR Eka.

Tugas dan Tanggung Jawab Dewan Komisaris BPR Eka dalam Pengawasan Strategis, Dewan Komisaris secara langsung melaksanakan pengawasan terhadap tugas dan tanggung jawab Direksi, dengan mengarahkan, memantau dan mengevaluasi implementasi kebijakan stratejik. Selanjutnya dalam pengawasan strategis, Dewan Komisaris memiliki kewenangan dalam menyetujui Pedoman Kebijakan Perkreditan BPR (PKPB), dan mengawasi Direksi dalam menjalankan PKPB apakah sudah sesuai atau masih ada kelemahan. Selain itu Dewan Komisaris memastikan Direksi telah menindak lanjuti temuan Audit, dan rekomendasi dari satuan kerja internal audit, eksternal audit, dan hasil pengawasan Otoritas Jasa Keuangan dan Otoritas lainnya.

Dalam hal pengawasan perusahaan, maka Dewan Komisaris memastikan terselenggaranya pelaksanaan tata kelola perusahaan yang baik pada setiap kegiatan usaha BPR Eka pada seluruh tingkatan jenjang organisasi. Dewan Komisaris juga dapat membentuk komite-komite yang relevan dengan dibuatkan pedoman dan tata tertib kerja yang jelas dan telah disetujui.

Berdasarkan penelitian di atas menunjukkan bahwa BPR Eka telah memiliki tata kelola yang baik dalam hal pelaksanaan tugas dan tanggung jawab Dewab Komisaris. Kondisi ini yang menjadikan Direksi BPR Eka selalu mendapat pengawasan yang baik dari Dewan Komisaris 
sehingga operasional berjalan lancar dan tidak melanggar kebijakan yang telah dibuat termasuk semua peraturan yang mengikat BPR Eka.

c. Tata Kelola Kelengkapan dan Pelaksanaan Tugas atau Fungsi Komite;

Dari hasil penelitian terhadap kelengkapan dan pelaksanan tugas atau fungsi komite, BPR Eka telah membentuk Komite Audit dan Komite Pemantau Risiko. Komite Audit dibentuk oleh Dewan Komisaris BPR Eka dalam rangka membantu Dewan Komisaris menjalankan tugas dan tanggung jawabnya, untuk melakukan pengawasan dan pemberian nasihat kepada Direksi, terkait dengan pengawasan dan evaluasi atas penerapan audit intern dan ekstern, kecukupan pengendalian intern dan termasuk proses pelaporan keuangan serta penerapan tata kelola yang baik.

Komite Pemantau Risiko dibentuk oleh Dewan Komisaris PT BPR Eka Bumi Artha dalam rangka membantu Dewan Komisaris menjalan-kan tugas dan tanggung jawabnya untuk melakukan pengawasan dan pemberian nasihat kepada Direksi, dan untuk memperoleh keyakinan agar manajemen risiko BPR Eka sesuai prosedur yang ditetapkan, sehingga kegiatan usaha BPR Eka dapat berjalan baik, terkendali dan menguntungkan.

Diungkapkan juga mengenai kualifikasi pendidikan, keahlian dan pengalaman anggota Komite Audit dan Komite Pemantau Risiko yang secara keseluruhan memiliki kesesuaian.

Dalam hal independensi anggota Komite Audit dan Komite Pemantau Risiko, secara keseluruhan tidak ada yang memiliki hubungan keuangan, kepemilikan dan keluarga atau semenda dengan derajat kedua dengan; sesama anggota Dewan Komisaris, Anggota Direksi, dan pemegang saham pengendali.

Komite Audit BPR Eka yang terdiri satu orang Ketua Komite dan dua orang Anggota Komite dan telah memiliki rincian tugas, tanggung jawab dan wewenang. Komite Audit di antaranya memiliki tugas dan tanggung jawab dalam memberikan rekomendasi kepada Dewan Komisaris. Komite Audit memantau dan mengevaluasi perencanaan dan pelaksanaan audit serta pemantauan atas tindak lanjut hasil audit.

Komite Pemantau Risiko terdiri atas satu orang Ketua Komite dan dua orang Anggota Komite, juga telah memiliki rincian tugas, tanggung jawab dan wewenang. Komite Pemantau Risiko di antaranya memiliki tugas dan tanggung jawab dalam memberikan rekomendasi terkait hasil pemantauan risiko. Tugas lainnya memberikan rekomendasi dengan melakukan evaluasi tentang kesesuaian antara kebijakan Manajemen Risiko dengan pelaksanaan kebijakan tersebut. Melakukan Review penerapan Manajemen Risiko yaitu laporan profil risiko, laporan tingkat kesehatan bank, laporan lainnya terkait dengan pengelolaan enam jenis risiko yaitu risiko kredit, risiko operasional, risiko kepatuhan, risiko likuiditas, risiko reputasi, dan risiko stratejik.

Berdasarkan pada penelitian dan penjelasan di atas maka BPR Eka telah memiliki sistem dan prosedur tata kelola bank yang baik karena Dewan Komisaris telah diangkat sesuai Peraturan Otoritas Jasa Keuangan. Dewan Komisaris dalam menjalankan tugasnya telah membentuk dua komite yang mendukung tugas dan tanggung jawabnya, yang memiliki peran besar dalam terselenggara-nya tata kelola BPR yang baik sesuai Peratran Otoritas jasa Keuangan dan Peraturan serta perudang-undangan lainnya yang terkait.

d. Tata Kelola Penanganan Benturan Kepentingan; Hasil penelitian pada tahun 2018, BPR Eka tidak terjadi benturan kepentingan. Namun demikian, BPR Eka sudah memiliki strategi dalam penanganan benturan kepentingan, hal ini dilakukan BPR Eka untuk menghindari pengambilan keputusan yang berpotensi merugikan atau mengurangi keuntungan. BPR Eka telah memiliki dan menerapkan kebijakan intern, sistem dan prosedur penyelesaian mengenai benturan kepentingan, meliputi penanganan benturan kepentingan yang mengikat setiap anggota Direksi, Dewan Komisaris, Komite dan Karyawan.

Berdasarkan penjelasan di atas, dengan tidak adanya benturan pada tahun 2018, menunjukkan bahwa tata kelola BPR Eka tergolong baik dan Direksi telah menyusun kebijakan yang tepat dan strategis dan mengikat dalam upaya mencegah terjadinya benturan kepentingan yang dapat merugikan operasional BPR.

e. Tata Kelola Penerapan Fungsi Kepatuhan, Audit intern, dan Audit ekstern;

Penerapan fungsi kepatuhan telah dilaksanakan BPR Eka dengan mengangkat Direktur Kepatuhan, sesuai keputusan pemegang saham tanggal 23 Mei 2017 dan telah dilaporkan serta ditatausahakan dalam administrasi pengawasan Otoritas Jasa Keuangan berdasarkan surat Nomor S-163/KO.741/2017 tanggal 13 Juli 2017.

BPR Eka juga telah membentuk Satuan Kerja Kepatuhan yang telah dilaksanakan berdasarkan Surat Keputusan Direksi No. 098/EBA/XII/2015 tanggal 28 Desember 2015 dan menetapkan Kepala Satuan Kerja Kepatuhan.

Penelitian pada laporan tata kelola BPR Eka, fungsi kepatuhan merupakan serangkaian tindakan atau langkah-langkah yang bersifat pencegahan untuk memastikan bahwa kebijakan, ketentuan, sistem, dan prosedur, serta kegiatan usaha yang dilakukan oleh BPR Eka telah sesuai dengan Peraturan dari Otoritas Jasa Keuangan, Perundang-undangan dan lembaga lainnya. Berdasarkan laporan tata kelola BPR Eka juga 
telah mengangkat Kepala Satuan Kerja Audit Internal yang dilakukan berdasarkan Surat Keputusan Direksi No. 089/EBA/XII/2015 tanggal 28 Desember 2015 dan menetapkan Kepala Satuan Kerja Audit, dalam rangka untuk membantu Direksi dalam rangka memastikan kepatuhan seluruh jenjang organisasi dalam melaksanakan kegiatan usaha atau operasional. Dalam hal penerapan fungsi Audit Ekstern, Rapat Saham Luar Biasa tanggal 22 November 2018 telah menetapkan penunjukkan Akuntan Publik/atau Kantor Akuntan Publik yang akan melakukan audit terhadap laporan keuangan historis tahun 2018. Sedangkan untuk Audit Ekstern dari Otoritas Jasa Keuangan yang merupakan pemeriksaan umum terhadap BPR Eka telah dilaksanakan pada tanggal 06 s.d 16 Agustus 2018, dan terhadap hasil temuan pemeriksaan dan rekomendasi dari OJK secara bertahap telah dipenuhi dan dilaporkan kembali kepada Otoritas jasa Keuangan.

Berdasarkan penjelasan diatas, menunjukkan bahwa BPR Eka memiliki tata kelola yang baik sebab telah menerapkan fungsi dan organisasi kepatuhan, Audit Intern dengan baik, sehingga jika mengadapi audit ekstern baik oleh Otoritas Jasa Keuangan maupun Kantor Akuntan Publik yang ditunjuk memiliki hasil penilaian yang baik. Direksi BPR Eka memiliki kepatuhan dalam menyampaikan perbaikan-perbaikan laporan hasil temuan dan rekomendasi pemeriksaan kepada Otoritas Jasa Keuangan.

f. Tata Kelola Penerapan Manajemen Risiko, termasuk Sistem Pengendalian Intern;

Berdasarkan hasil penelitian yang bersumber dari laporan tata kelola BPR, berhubungan dengan Penerapan Manajemen Risiko secara komprehensif dan terpadu, mengacu pada Peraturan Otoritas Jasa Keuangan No. 13/POJK.13/2015 tentang Penerapan Manajemen Risiko bagi Bank Perkreditan Rakyat.

Penerapan Manajemen Risiko BPR Eka meliputi; Pengawasan Dewan Komisaris, Kecukupan kebijakan, Prosedur dan Limit, yaitu: Kebijakan Manajemen Risiko, Prosedur Manajemen Risiko, dan Penetapan Limit Risiko. Selanjutnya mengenai Kecukupan proses dan sistem dan Pengendalian intern yang menyeluruh.

Penelitian yang bersumber pada laporan tata kelola tahun 2018, BPR Eka dalam rangka pengawasan atas penerapan manajemen risiko, Direksi dan Komisaris telah menetapkan organisasi, dan pejabat yang bertanggung jawab, serta menetapkan wewenang dan tanggung jawab yang jelas pada setiap jenjang jabatan yang terkait dengan penerapan manajemen risiko. Berdasarkan pada penjelasan di atas, BPR Eka telah menerapkan tata kelola bank yang baik dan sehat. Hal ini ditunjukkan dengan diterapkannya Manajemen Risiko dengan kebijakan yang sesuai dengan peraturan dan telah membentuk organisasi dan pejabat yang bertanggung jawab.

g. Tata Kelola Batas maksimum pemberian kredit; Hasil penelitian terhadap laporan tata kelola BPR Eka tahun 2018 mengenai Batas Maksimum Pemberian Kredit BPR Eka, tidak melakukan pelanggaran dan pelampauan baik perorangan maupun kelompok (group). Dalam penyediaan dana kepada pihak terkait dan kepada debitur besar, BPR Eka telah menerapkan prinsip kehatihatian dalam penyediaan dana kepada pihak terkait, penyediaan dana besar dan Batas Maksimum Pemberian Kredit (BMPK).

Berdasarkan data tersebut maka BPR Eka telah memiliki Tata Kelola yang baik dalam menjaga agar kredit yang diberikan tidak melanggar ketentuan BMPK, baik kepada pihak terkait maupun kelompok. Penerapan prinsip kehatihatian menjadikan BPR pada akhir Desember 2018 tidak terdapat penyediaan dana kepada pihak terkait dan pada posisi Desember 2018 penyediaan kepada 25 debitur besar (inti) dengan outstanding sebesar Rp. 20.618.352.538,- atau $3,30 \%$ dari modal dan $0,32 \%$ dari total kredit yang diberikan.

h. Tata Kelola Rencana bisnis BPR;

Hasil penelitian pada laporan tata kelola BPR menunjukkan Direksi memiliki tiga tipe rencana bisnis, yaitu Rencana Jangka Pendek, Rencana Jangka Menengah dan Rencana Jangka Panjang. Untuk Rencana Jangka Pendek, memuat strategi pemberian kredit, strategi penghimpunan dana, dan strategi pengendalian kredit bermasalah. Dalam Rencana Jangka Menengah, Direksi menyusun strategi pemberian kredit, strategi penghimpunan dana, strategi pengendalian kredit bermasalah dan strategi pengembangan modal. Selanjutnya dalam Rencana Jangka Panjang, berdasarkan Arah Kebijakan Bank, maka langkah-langkah strategis yang akan ditempuh untuk mewujudkan visi dan misi bank meliputi, strategi pemberian kredit, kebijakan penghimpunan dana, dan strategi perluasan jaringan kantor, strategi pengembangan organisasi dan teknologi sistem informasi, strategi untuk mengantisipasi perubahan kondisi eksternal. Dalam laporan perhitungan laba rugi tahun 2018, perolehan laba BPR Eka telah melampaui target, dimana laba (rugi) neto tahun 2018 ditargetkan sebesar Rp. 208.161.028.000,-, pada realisasinya dapat dicapai sebesar Rp. 226.364.525.000,- atau mencapai 108,74\%.

Berdasarkan penjelasan di atas, menunjukkan bahwa BPR Eka telah memiliki tata kelola yang baik dalam menyusun rencana kerja baik dalam jangka pendek, jangka menengah dan jangka panjang. Rencana kerja ini memberikan gambaran bagaimana Direksi berupaya untuk mewujudkan visi dan misi menjadi BPR yang sehat dan kuat. Dengan rencana kerja yang lengkap akan menjadi 
pedoman dalam mencapai target yang telah ditetapkan. Keberhasilan dalam mencapai target laba 108,74\% menunjukkan tata kelola BPR Eka dilaksanakan secara konsisten sehingga memberikan hasil yang terbaik.

i. Tata Kelola Transparansi kondisi keuangan dan non keuangan.

Hasil penelitian laporan tata kelola BPR tahun 2018, transparansi kondisi keuangan dituangkan secara jelas dan transparan dalam bentuk Laporan Keuangan Tahunan, Laporan Keuangan Publikasi dan Laporan Non Keuangan BPR Eka.

Dalam laporan keuangan tahunan di ungkap mengenai ikhtisar data keuangan penting, manajemen dan organisasi, Laporan Direksi atas pelaksanaan kerja dan anggaran perusahaan, tata kelola perusahaan serta laporan pengawasan Dewan Komisaris. Selain itu juga disajikan Laporan Keuangan Tahunan yang telah diaudit oleh Akuntan Publik yang telah didaftar di Otoritas jasa Keuangan dan dibuat untuk satu tahun buku dan disajikan dalam bentuk perbandingan satu tahun buku sebelumnya dan dilaporkan ke Otoritas Jasa Keuangan sesuai dengan waktu yang telah ditentukan.

Laporan keuangan publikasi BPR Eka ditanda tangani oleh Direksi sesuai dengan format yang disediakan oleh Otoritas Jasa Keuangan, untuk dipublikasikan melalui website BPR dan/atau pada papan pengumuman pada setiap kantor sesuai dengan ketentuan yang berlaku.

Dalam hal laporan non keuangan bank, BPR Eka telah memberikan informasi mengenai produk secara jelas dalam bentuk pelayanan lansung oleh petugas terkait atau melalui banner, brosur atau bentuk tertulis lainnya di seluruh kantor.

Berdasarkan penjelasan di atas menunjukkan bahwa BPR Eka telah melaksanakan tata kelola yang baik dalam hal transparansi kondisi keuangan dan non keuangan. Dalam transparansi kondisi keuangan telah dibuatkan laporan tahunan yang dapat dipertanggungjawabkan kebenarannya melalui pemeriksaan Akuntan Publik. Laporan publikasi BPR dibuat sesuai ketentuan Otoritas Jasa Keuangan dan telah dilaporkan setiap tiga bulan. Laporan publikasi dapat diakses dengan mudah dan cepat melalui website BPR Eka, sehingga dapat menjadi sumber informasi kepada nasabah atau masyarakat umum yang memerlukan informasi keuangan BPR Eka. Dalam laporan non keuangan, BPR Eka telah menginformasikan kepada masyarakat secara langsung maupun media cetak dan internet. Dalam hal pengaduan nasabah BPR Eka telah menanganinya dengan baik sesuai ketentuan pengaduan nasabah.

Berdasarkan dari kesimpulan hasil penilaian sendiri (self assessment) atas penerapan tata kelola yang dilakukan BPR Eka yang tercantum dalam laporan tata kelolan BPR Eka tahun 2018, di samping aspek positif yang sudah dilakukan, akan tetapi masih terdapat beberapa aspek negatif, yaitu dalam hal struktur dan infrastruktur tata kelola yang belum sepenuhnya tersusun dan masih memerlukan pengkinian data. Selain itu masih terdapat aspek negatif terkait hasil tata kelola dalam penyediaan SDM yang dapat menopang volume usaha BPR yang terus berkembang yang berdampak pada sangat tingginya rasio aset yang dikelola setiap karyawan. Kebaruan penelitian ini dari yang sudah ada adalah dalam penelitian ini penulis lebih spesifik dalam memastikan bahwa BPR Eka Bumi Artha sebagai BPR terbesar di Indonesia dan selalu mendapat penghargaan sejak tahun 2011, terbukti didukung dengan adanya penerapan tata kelola perusahaan yang baik sesuai Peraturan Otoritas Jasa keuangan Nomor 4/POJK.03/2015 tentang Penerapan Tata Kelola Bagi Bank Perkreditan Rakyat. Penelitian bersumber dari laporan Tata Kelola yang dapat dipertanggung jawabkan kebenarannya.

\section{KESIMPULAN}

Berdasarkan pada hasil dan pembahasan penelitian yang telah dilakukan dengan cara mengevaluasi laporan tata kelola bank tahun 2018 dapat disimpulkan sebagai berikut :

1. Secara keseluruhan BPR Eka Bumi Artha telah melaksanakan Peraturan Otoritas Jasa keuangan (POJK) Nomor 4/POJK.03/2015 tentang Penerapan Tata Kelola Bagi Bank Perkreditan Rakyat

2. BPR Eka Bumi Artha memiliki kepatuhan dalam melaksanakan prinsip-prinsip tata kelola yang meliputi keterbukaan (transparency), akuntabilitas (accountability), pertanggung jawaban (responsibility), independensi (independency), dan kewajaran (fairness).

3. BPR Eka Bumi Artha telah melaksanakan seluruh lingkup tata kelola seperti tertuang dalam Peraturan Otoritas Jasa Keuangan. Seluruh Direksi dan Dewan Komisaris serta seluruh komite yang dibentuk dan diorganisasikan secara tepat dan sesuai peraturan tata kelola, telah menjalankan tugas dan tanggung jawabnya secara baik. Tidak adanya benturan kepentingan yang terjadi selama tahun 2018.

4. Hasil penelitian ini membuktikan bahwa dengan penerapan tata kelola yang baik, kinerja keuangan BPR Eka tahun 2018 dalam bentuk perolehan laba mengalami peningkatan dan telah melampaui target laba yang direncanakan.

Terdapat beberapa saran peneliti yang perlu menjadi perhatian manajemen BPR Eka yaitu:

1. BPR Eka Perlu melakukan monitoring yang tepat dalam tata kelola manajemen risiko dengan adanya kepastian bahwa kebijakan dan SOP terkait harus selalu dilakukan pengkinian sesuai perkembangan usaha BPR dan peraturan dari 
Otoritas Jasa Keuangan, LPS, Bank Indonesia, dan perundangan lainnya yang terkait.

2. Dengan semakin besarnya volume usaha BPR Eka, maka Direksi dalam tata kelola terkait rencana bisnis, perlu dicantumkan secara spesifik strategi pengembangan SDM baik dari kuantitatif maupun kualitatif sebagai modal utama dalam memajukan bisnis BPR Eka dan pencapaian kinerja yang lebih baik lagi.

Diharapkan penelitian berikutnya dapat membahas mengenai teknis dalam penilaian sendiri (Self assessment) atas penerapan tatakelola BPR.

\section{REFERENSI}

Dharmawan, N. K. S., \& Kurniawan, I. G. A. (2018). Fungsi Pengawasan Komisaris Terkait Kesehatan Bank Perkreditan Rakyat: Pendekatan Good Corporate Governance Dan Asas Itikad Baik. Jurnal Law Reform, 14(2), 236-247.

Fajri, D. E. N. (2017). Implementasi Prinsip Tata Kelola Perusahaan Yang Baik (Good Corporate Governance) PT Bank Perkreditan Rakyat (BPR) Karya Utama Jawa Barat Dalam Mewujudkan Kepastian Hukum. Repository Unpas.

Kurniasari, R. (2019). Pengaruh Kualitas Pelayanan Terhadap Peningkatan Kepuasan Pelanggan Pada Hotel Bogor. Jurnal Widya Cipta, 3(1), 13.

Mudashiru, A., Bakare, I. A. ., Babatunde, Y., \& Ishmael, O. (2014). Good Corporate Governance and Organisational Performance : An Empirical Analysis. 4(7), 170-178.

Nurdin. (2015). Analisis Pengaruh Tata Kelola Perusahaan yang Baik Terhadap Keunggulan Bersaing Pada Bank Perkreditan Rakyat. Jurnal Manajemen Dan Bisnis, XII(1), 122-135.

Otoritas Jasa Keuangan. (2015). Peraturan Otoritas Jasa Keuangan Nomor 4/POJK.03/2015 Tentang PenerapanTata Kelola Bagi Bank Perkreditan Rakyat.

Riyanto, A. (2018). Implikasi Kualitas Pelayanan Dalam Meningkatkan Kepuasan Pelanggan Pada PDAM Cibadak Sukabumi. Jurnal Ecodemica, 2(1).

Sawitri, P. P., \& Ramantha, I. W. (2018). Pengaruh Penerapan Prinsip-prinsip Good Corporate Governance Pada Kinerja Bank Perkreditan Rakyat di Kota Denpasar. E-Jurnal Akuntansi, 23(2), 1093-1118.

Sundari, H. (2014). Evaluasi Penerapan Good Corporate Governance Pada Bank PD BPR Sarimadu. Jurnal Sorot, 9(1), 43-58.

Supeno, W. (2017). Analisis Kinerja Penghimpunan Dana dalam Meningkatkan Penyaluran Kredit pada Bank Perkreditan Rakyat. Jurnal Moneter, IV(2), 121-131.

Supeno, W. (2018). Implementasi Kualitas
Pelayanan di Era Disrupsi Pada PD BPR Bank Jombang Jawa Timur. 2(2), 255-262.

Supeno, W. (2019). Analisis Efisiensi BOPO Terhadap Laba Bersih Pada BPR. Jurnal Kajian Ilmiah, 19(2), 182-194.

Wijayanti, D., \& Hutapea, T. (2019). Tingkat Kepatuhan Pelaksanaan Tata Kelola BPR Setelah Diberlakukannya Peraturan OJK Tentang Penerapan Tata Kelola BPR Di Wilayah Kerja Kantor OJK Malang. Jurnal Bisnis Dan Manajemen, 6(1), 15-23.

\section{PROFIL PENULIS}

${ }^{1}$ Wangsit Supeno, SE, MM, lahir di Jakarta, saat ini aktif sebagai dosen tetap pada Universitas Bina Sarana Informatika (UBSI) sejak tahun 2002.

Selain mengajar di kampus UBSI, saya menekuni aktivitas sebagai Trainerpreneur dan Coach preneur. Saat ini menjabat Komisaris Utama pada PT Kolaborasi Cahaya Mulia (KCM) di bidang Pengembangan Diri. Aktivitas organisasi menjabat sebagai Membership Director ASESCO (Asosiasi ESQ 3.0 Coaching), anggota The Indonesian Board of Hypnotherapy (IBH) dan anggota Asosiasi Dosen Indonesia (ADI). Telah menulis jurnal ilmiah yang dapat diakses melalui Google Scholar dan Sinta.

${ }^{2}$ Vina Islami, S.Pi, MM, lahir di Bima 25 Desember 1985, menyelesaikan S1 pada Program Studi Sosial Ekonomi Perikanan dan Kelautan, Fakultas Perikanan dan Ilmu Kelautan Institut Pertanian Bogor (FPIK IPB) tahun 2008. Tahun 2010 menyelesaikan program Magister Manajemen Bisnis pada Sekolah Bisnis Institut Pertanian Bogor (SB - IPB). Mengajar pada Program Studi Administrasi Bisnis Fakultas Ekonomi dan Bisnis pada Universitas Bina Sarana Informatika (UBSI) dari Maret 2013 sampai sekarang. Saat ini Jabatan Fungsional Dosen adalah Asisten Ahli Kum 150. 